\title{
The Effect of Plant Growth Regulator and Active Charcoal on the Development of Microtubers of Potatoes
}

\author{
Maolin Peng, Xiyao Wang ${ }^{*}$, Liqin Li \\ College of Agronomy, Sichuan Agricultural University, Chengdu, China. \\ Email: *wxyrtl@163.com \\ Received August $4^{\text {th }}, 2012$; revised September $15^{\text {th }}, 2012$; accepted October $7^{\text {th }}, 2012$
}

\begin{abstract}
With the detoxicated seedling of a potato cultivation breed named "Mire" as the material, the effect of auxins CCC, 6-BA, and active carbon to microtubers of potato (Solanum tubersum L.) was investigated under the in-vitro circumstances. The result indicated the exogenous auxins improved the production and quality of microtubers of potatoes. The effect of induction can be described as $\mathrm{CCC}>\mathrm{CCC}+6-\mathrm{BA}>6$-BA $>\mathrm{CK}$, the number of microtubers in per flask is $8.17>7.67>7.29>5.46$, and the number of large potatoes in per flask is $6.33>5.17>3.17>1$. In addition, by adding $0.5 \%$ of active charcoal, the growth period was shortened from 25.0 days to 9.33 days on average, and the amount of larger potatoes increased $8.54 \%$. These results benefited the growth of microtubers of potato.
\end{abstract}

Keywords: Plant Growth Regulators; Active Charcoal; Microtubers of Potato

\section{Introduction}

Potato (Solanum tubersum L.) is crucial crops to economies. They are cultivated around the world with an average annual cultivation area beyond 20 million $\mathrm{hm}^{2}$. It has the fourth greatest global production [1]. China, which area of cultivation is around 3 million to 3.33 million $\mathrm{hm}^{2}$, is the second largest area of potato cultivation in the world [2]. Potatoes are praised by its short growth period, high adaptability and production, great potential of yield increase, and et al. Potatoes mainly reproduce asexually. Its degeneration causes its quality and quantity produced to drop [3]. With the development of the plant meristem culture, it was possible to produce detoxicated "rejuvenated" potatoes. This could solve the global issue of seed potato degeneration [2]. Ever since the success of the induction of microtubers [4], experts around the world had started thorough studies on this and seen relatively great improvements [5-7]. Microtubers of potatoes have outstanding advantages as small volume, light weight, unlimited producing seasons, easy to storage, faster reproducing rate comparing to average agricultural production, and high cultivation survival rate[8]. Microtubers can be used to exchange the germplasm resources. Their production and transportation are more convenient than other forms of germplasm. Other than this, microtubers play the role of receptors of gene transfer in contemporary studies of potato genes engineering. In addi-

\footnotetext{
"Corresponding author.
}

tion, it is an ideal method to study the tuber formation mechanism of potatoes by inducing the formation of potato tubers under in-vitro circumstances [9].

Fundamental principles of the formation of microtubers are extremely complicated, because their formation is influenced by multiple factors including, temperature [10], genotype, age, health of the plantlets, as well as mineral nutrition [11], carbon source [12], exogenous auxins $[13,14]$, method, the plant growth retardants [15], other adjunctions, the illumination [16] and other environmental factors. However, different breeds of potatoes have relatively different level adaptability to the planting conditions. There's no universal and high effective induction method for microtubers of potatoes, which resulted inconvenience for our agricultural production and studies. The purpose is to produce high-quality microtubers at a low cost, which is significantly meaningful for the occurrence of future agricultural production and experimental work.

\section{Materials and Methods}

The virus-free seedlings of potato "Mire" was obtained from the potato Research Centre of Sichuan Agriculture University. The sterile explants "Mire" were cut into stem pieces with a single or two axillary buds, and inoculated vertically into a flask $(100 \mathrm{ml})$ with $20 \mathrm{ml}$ of initiation MS medium [17], containing 3\% (w/v) sucrose and $0.7 \%(\mathrm{w} / \mathrm{v})$ agar according to a standard yam nodal segment culture protocol $[18,19]$, the $\mathrm{pH}$ was adjusted to 
pH 5.8. There were 9 nodal explants per flask. And they were incubated under controlled environmental conditions of $18^{\circ} \mathrm{C} \pm 2^{\circ} \mathrm{C} .16 / 8$ light/dark cycles and the illumination intensity at $2000 \mathrm{~lx}$, which were fostered for about 3 weeks, they were cultured under the same conditions to cultivate sufficient seedlings to induce microtubers. Subsequently, one hundred and eight health explants were removed from the MS medium and then plant them into the inducting medium of microtubers (see Table 1). 6 separate explants were placed into each bottles, and each treatment need 6 bottles; repeat each treatment thrice in total. Place and foster the cultured materials into the organized fostering room. Keep the temperature at $18^{\circ} \mathrm{C} \pm 2^{\circ} \mathrm{C}$, and the illumination intensity at $2000 \mathrm{~lx}$ for 8 hours per day.

Observations were recorded on the number of microtubers and the size of microtubers. Count all microtubers on the $40^{\text {th }}$ day, and then count the number of unpolluted potatoes (potato/bottle), individual plant of microtubers (plant/bottle), and larger potato (diameter $>5 \mathrm{~mm}$ ), get average number of each treatments; Analysis of variance was calculated for the data using the SPSS version 13.0 statistical package for Windows. The Figures 1 and 2 were completed by the Excel 2003.

The formula for the result would be:

Percentage of large potatoes $=$ number of large potatoes/total number of potatoes $\times 100 \%$ (Diameter $>5 \mathrm{~mm}$ ).

Percentage of potato in individual plant $=$ total number of potatoes fructified per bottle/number of inoculated individual plant per bottle $\times 100 \%$.

\section{Conclusion and Analysis}

\subsection{The Influence of Exogenous Auxins on Microtubers of Potatoes Induction}

Judging from the result observation on the 5th day of induction fostering, the pure CCC treatment fructified microtubers at the earliest; the lower part of the potato plantlets' stem segments started turning purple and expanding. Later on, the same phenomenon was observed in other treatments. Among all the four different treatments, treatment III had the highest average production of potatoes, which were 8.17. Treatment V ranked second, with an average production of 7.67 potatoes. Treatment IV had the third highest production of potatoes, which was 7.29 , and the plain control group produced only 5.46 potatoes on average. As seen in Figure 1, the number of potatoes fructified in the four treatments increased as the inducing time increased. Their relationship can be classified as: Treatment III $>$ Treatment $\mathrm{V}>$ Treatment IV > Treatment II. Treatment I (CK) contained no exogenous auxins; potatoes planted in this treatment fruited relatively later and less. Therefore, the influential level of the four treatments on the induction
Table 1.Composition of inducing subculture media.

\begin{tabular}{|c|c|c|}
\hline Treatment & Subculture Media & $\mathrm{PH}$ \\
\hline I & MS $+8 \%$ Sucrose $+0.8 \%$ Agarose & 5.8 \\
\hline II & $\begin{array}{c}\text { MS }+8 \% \text { Sucrose }+0.5 \% \text { Active Carbon } \\
+0.8 \% \text { Agarose }\end{array}$ & 5.8 \\
\hline III & $\begin{array}{c}\text { MS + 8\%Sucrose + CCC } 5 \mathrm{mg} / \mathrm{L} \\
+0.5 \% \text { Active Carbon }+0.8 \% \text { Agarose }\end{array}$ & 5.8 \\
\hline IV & $\begin{aligned} & \mathrm{MS}+8 \% \text { Sucrose }+6-\mathrm{BA} 5 \mathrm{mg} / \mathrm{L} \\
+ & 0.5 \% \text { Active Carbon }+0.8 \% \text { Agarose }\end{aligned}$ & 5.8 \\
\hline V & $\begin{array}{c}\mathrm{MS}+8 \% \text { Sucrose }+ \text { CCC } 5 \mathrm{mg} / \mathrm{L}+6-\mathrm{BA} 5 \mathrm{mg} / \mathrm{L} \\
+0.5 \% \text { Active Carbon }+0.8 \% \text { Agarose }\end{array}$ & 5.8 \\
\hline
\end{tabular}

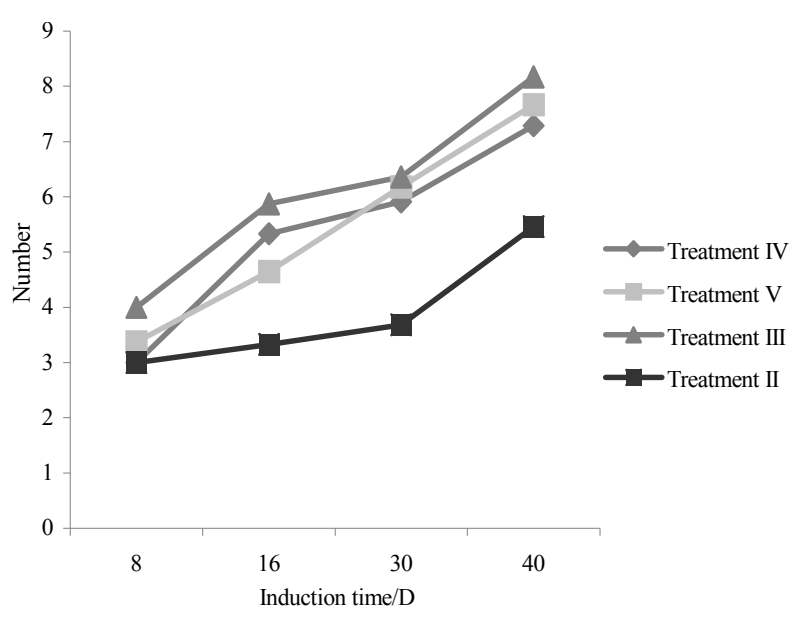

Figure 1. Influence of exogenous auxins on the development of microtubers "Mire".

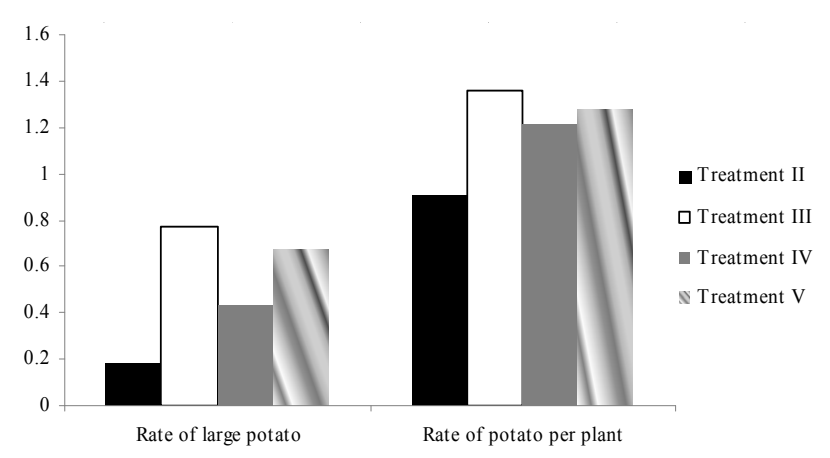

Figure 2. Effect of exogenous auxins on microtubers' development.

effect of the microtubers, can be described as: $\mathrm{CCC}>6$ $\mathrm{BA}+\mathrm{CCC}>6-\mathrm{BA}>$ control group (Figure 1).

\subsection{The Influence of Exogenous Auxins on the Development}

As seen in Table 2, it's easy to tell, with the help from the F-test of One-Way Anova, the difference in the number of fruited potatoes and large potatoes per bottle 
is significant among treatment III, IV, V, and II, which is the plain control group (Table 2). This proves adding appropriate amount of exogenous auxins can increase the induction of microtubers and surpass non-adjunction experimental groups on both quality and quantity.

As seen in Table 3 and Figure 2, Treatment III's average value of fruited potatoes, large potatoes (Table 3), percentage of potatoes fruited on individual plant and percentage of large potatoes ranked the highest among the four. It's easy to see an extremely significant difference on the amount of fruited potatoes and large potatoes per bottle between treatment III and the control group. There is also an obvious difference on the percentage of large potatoes, percentage of potatoes fruited on individual plant and the number of fructified potatoes per bottle between treatment III and other treatments. After adding the CCC, the percentage of large potatoes dramatically increased, proving the $\mathrm{CCC}$ greatly promoted the nutrient accumulation of the microtubers of potatoes. Possibly because of the lack of CCC, there was no dramatic difference observed between the number of potatoes fructified per bottle and the treatment with 6-BA.

\subsection{The Influence of Active Carbon on Microtubers of Potatoes' Induction}

As seen in Table 4, the subculture media with $0.5 \%$ ac- tive carbon more rapidly induced bigger potatoes than the other control group media without it. The large potato percentage increased by $8.54 \%$ and the time needed to fructify the microtubers dramatically shortened. However, because of the numerous small potatoes produced in the control groups, the percentage of potatoes fructified on each plant in the active carbon media is actually less. In the early period of the experiment, the colors of the microtubers in the two different treatments seemed to differ dramatically. As illustrated in Figures 3 and 4, the microtubers grown from the subculture medium with active carbon appeared brown at first. On the other hand, the ones grown from the control group medium appeared green. As time went by, the brown lightened. When the fructified potatoes induced from the subculture media with active carbon were gathered on the 40th day, they had turned into green, as seen in Figure 4. The active toner might have prevented light from reaching the plantlets, potentially causing this color change. As the plantlets grew little by little, the preventing effect seemed to wear off.

\section{Discussion}

Microtubers' propagation is controlled by many factors. When conditions are suitable, it can generate microtubers without auxins. However, this will lengthen the forming

Table 2. The effect of exogenous auxins on the induction on the microtubers.

\begin{tabular}{|c|c|c|c|c|c|c|}
\hline Factor & SS & $\mathrm{df}$ & MS & $\mathrm{F}$ & P-value & Fcrit \\
\hline Between group (laeger potato number) & 98.83333 & 3 & 32.94444 & $31.37566^{* *}$ & $9.27 \mathrm{E}-08$ & 3.098391 \\
\hline Within group & 21 & 20 & 1.05 & & & \\
\hline Between group (potato number) & 94.3333 & 3 & 31.44444 & $36.99346^{* *}$ & $2.37 \mathrm{E}-08$ & 3.098391 \\
\hline Within group & 17 & 20 & 0.85 & & & \\
\hline
\end{tabular}

Note: F-test of one-way anova.

Table 3. Effect of exogenous auxins on microtubers' induction and development.

\begin{tabular}{ccccc}
\hline Treatment & Microtuber of per flask & Large potato & Rate of lager potato (\%) & Rate of potato per plant (\%) \\
\hline II (CK) & $5.46 \mathrm{~B}$ & $1 \mathrm{~B}$ & $18.32 \%$ & $91 \%$ \\
III & $8.17 \mathrm{~A}$ & $6.33 \mathrm{~A}$ & $77.48 \%$ & $136.17 \%$ \\
IV & $7.29 \mathrm{~A}$ & $3.17 \mathrm{~B}$ & $43.48 \%$ & $121.5 \%$ \\
V & $7.67 \mathrm{~A}$ & $5.17 \mathrm{~A}$ & $67.41 \%$ & $127.83 \%$ \\
\hline
\end{tabular}

Note: Duncan's single factor test was performed at the 0.01 level.

Table 4.The effect of active carbon on microtubers of potatoes' induction.

\begin{tabular}{ccccc}
\hline Treatment & Time/d & Rate of large potato (\%) & Rate of potato per plant (\%) & Color \\
\hline I (CK) & 25.07 & $18.96 \%$ & $108.33 \%$ & green \\
II & 9.33 & $27.5 \%$ & $91 \%$ & brown \\
\hline
\end{tabular}




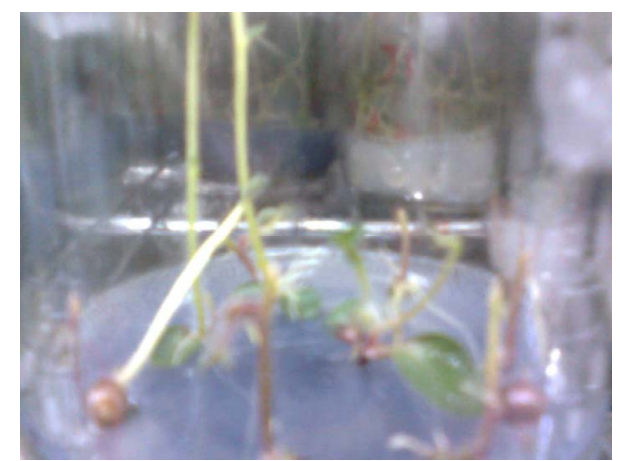

Figure 3. The effect of no active carbon on microtubers of potatoes' induction.

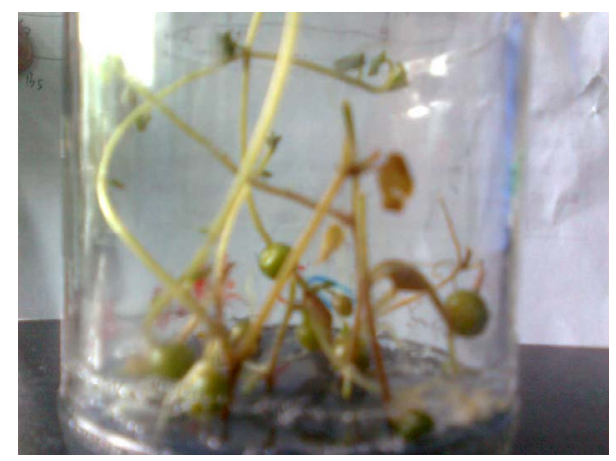

Figure 4. The effect of active carbon on microtubers of potatoes' induction.

time and lower the quantity of large potatoes produced, which hinders the producing industry. Adding exogenous auxins is a good way to reduce fructifying time and enhance the quality and yield of microtubers. There are many different exogenous auxins to choose from, but the $\mathrm{CCC}$ and the 6-BA are the most frequently found ones in China [20]. Cytokinins can promote potatoes' tuberization and are considered to be tuber-inducing factors [2125]. Among these; 6-BA is the most significant one, which is considered to promote the cell division and growth, to stimulate the activity of some enzymes, and to make the nutrients be transported to the parts of cytokinins more easily. So it performs to increase the potato number and weight at the same time [26]. As a plant growth inhibitor, the $\mathrm{CCC}$ is most frequently used for microtuber induction. It is also considered a dominant regulator. The CCC remarkably helps to fructify the tubers, to increase the production, and to enhance the effect of cytokinins. The contents of sucrose and starch increased in tubers when treated with CCC [27]. In the experiment, microtubers were formed in the treatments of 6-BA, 6-BA and CCC. 6-BA increased the number of microtubers, however, the number of large potato was lower than the treatment of CCC and 6-BA. This indicated that $\mathrm{CCC}$ played a main role. Although microtubers were formed both in the treatments of $\mathrm{CCC}$ and 6-BA +
$\mathrm{CCC}$, the former was proved more efficient than other treatments, for it had the highest number of potatoes produced, highest number of large potatoes produced, highest rate of large potatoes and highest number of single-plant potatoes produced. Especially, its number of large potato produced was nearly twice of the 6-BA treatment. According to Bai [26], adding a certain concentration of exogenous auxins does well in improving the yield and quality of microtubers .The effect is 6-BA $>$ $6-\mathrm{BA}+\mathrm{CCC}>\mathrm{CCC}>\mathrm{CK}$. But the experiment of Pang gets completely opposite conclusion, which is $\mathrm{CCC}>$ $\mathrm{CCC}+6-\mathrm{BA}>6-\mathrm{BA}$, and has an extreme influence of no root, no elongation, no microtubers with the treatment of 6-BA [26]. The result of our experiment is $\mathrm{CCC}>\mathrm{CCC}$ $+6-\mathrm{BA}>6-\mathrm{BA}>\mathrm{CK}$, which is similar to the experiement conducted by Pang [28], the different concentration of CCC plays a positive role in microtubers, but if the concentration of CCC is too high, it can be inhibited by 6-BA in some degree. Compared with the experiment of $\mathrm{Bai}$, the materials are different, which may lead to the different result. Activated charcoal is an adsorbent, which has a significant effect on the microtuber induction. It can increase tuber yield and greatly shorten the time of microtuber induction [29,30]. The color of early potato in the treatment with active charcoal was brown at first, and the color of microtubers in the treatment without it appeared green. The reason for this might have been that the activated charcoal blocked much of the lighting, and the activated charcoal kept a balance between the major elements and the minor elements in the culture medium.

In the experiment, we have found the growth of microtubers is related to the age and health of its explant. Older vines' nodes are more easily fructified than younger ones. The rate of lower vines appears higher than it of upper vines. They have found similar phenomena earlier [31]. However, the terminal bud is relatively easy to germinate under illumination circumstances. Therefore, the dark treatment is necessary to the explants.

\section{REFERENCES}

[1] FAO, "Potatoes in the 1990s: Situations and Prospects of World Potato Economy," Publications, Food and Agriculture Organization, 1998.

[2] J. He, Y. Chen and Y. S. Zhang, "Induction of Potato Microtuber in Vitro," Journal of Yunnan University, Vol. 1, No. 23, 2001, pp. 62-64.

[3] K. Kawakami, "The Physiological Degeneration of Potato Seed Tubers and Its Control," Potato Research, Vol. 5, No. 1, 1962, pp. 40-49. http://link.springer.com/article/10.1007\%2FBF02367660

[4] Y. Kim, "In Vitro Tuber Formation from Potato," Seoul University Publishing, Seoul, 1982. 
[5] M. J. Hossain and N. Sultana, "Effect of Benzyl Amino Purine (BAP) and Chloro Choline Chloride (CCC) on in Vitro Tuberization of Potato," Bangladesh Journal of Agriculture Research, Vol. 4, No. 23, 1998, pp. 685-690.

[6] J. Gopal, J. L. Minocha and H. S. Dhaliwal, "Microtuberization in Potato (Solanum tubersum L.)," Plant Cell Reports, Vol. 17, No. 10, 1998, pp. 794-798. doi:10.1007/s002990050485

[7] R. Estrada, P. Tovar and J. H. Dodds, "Introduction of in Vitro Tubers in a Broad Range of Potato Genotypes," Plant Cell, Tissue and Organ Culture, Vol. 7, No. 1, 1986, pp. 3-10. doi:10.1007/BF00043915

[8] J. L. John, W. H. Courtney and D. R. Decoteau, "The Influence of Plant Growth Regulators and Light on Microtuber Induction and Formation in Dioscorea alata L. Cultures," Plant Cell, Tissue and Organ Culture, Vol. 34, No. 3, 1993, pp. 245-252. doi:10.1007/BF00029713

[9] W. S. Hao, Y. X. Zhao and Q. H. Gao, "The Progress of Potato Microtubers Induction in China," Inner Monglia Agricultural Science and Technology, Vol. 6, 2002, pp. 4-7.

[10] M. E. Hoque, "In Vitro Tuberization in Potato (Solanum tuberosum L.)," Plant Omics Journal, Vol. 1, No. 3, 2010, pp. 7-11.

[11] D. Sarkar and P. S. Naik, "Effect of Inorganic Nitrogen Nutrition on Cytokinin-Induced Potato Microtuber Production in Vitro," Potato Research, Vol. 41, No. 3, 1998, pp. 211-217. doi:10.1007/BF02358191

[12] O. O. Paul, K. Claire and D. Jacques, "Effects of Reducing Sugar Concentration on in Vitro Tuber Formation and Sprouting in Yam (Dioscorea cayenensis-D. rotundata Complex)," Plant Cell, Tissue and Organ Culture, Vol. 99, No. 1, 2009, pp. 55-59. doi:10.1007/s11240-009-9575-1

[13] O. Mahmoud, C. S. Farhad and N. Paul, "Effects of Temperature Fluctuation during in Vitro Phase on in Vitro Microtuber Production in Different Cultivars of Potato (Solanum tubersum L.)," Plant Cell, Tissue and Organ Culture, Vol. 98, No. 2, 2009, pp. 213-218. doi:10.1007/s11240-009-9554-6

[14] K. Pruski, T. Astatkie, P. Duplessis, T. Lewis, J. Nowak and P. C. Struik, "Use of Jasmonate for Conditioning of Potato Plantlets and Microtubers in Greenhouse Production of Minitubers," American Journal of Potato Research, Vol. 80, No. 3, 2003, pp. 183-193. doi:10.1007/BF02855690

[15] P. Kris, A. Tess and N. Jerzy, "Jasmonate Effects on in Vitro Tuberization and Tuber Bulking in Two Potato Cultivars (Solanum tubersum L.) under Different Media and Photoperiod Conditions," In Vitro Cellular \& Developmental Biology-Animal, Vol. 38, No. 2, 2002, pp. 203209.

http://rd.springer.com/article/10.1079/IVPIVP2001265

[16] Janet E. A. Seabrook, "Light Effects on the Growth and Morphogenesis of Potato (Solanum tubersum) in Vitro: A Review," American Journal of Potato Research, Vol. 82, No. 5, 2005, pp. 353-367.

http://rd.springer.com/article/10.1007/BF02871966
[17] T. Murashige and F. Skoog, "A Revised Medium for Rapid Growth and Bioassays with Tobacco Tissue Cultures," Physiologia Plantarum, Vol. 15, No. 3, 1962, pp. 473-497. doi:10.1111/j.1399-3054.1962.tb08052.x

[18] S. H. Mantell, S. Q. Haque and A. P. Whitehall, "Clonal Multiplication of Dioscorea alata L. and Dioscorea rotundata Poir. Yams by Tissue Culture," The Journal of Horticultural Science, Vol. 53, No. 2, 1978, pp. 95-98.

[19] S. H. Mantell and S. A. Hugo, "Effects of Photoperiod, Mineral Medium Strength, Inorganic Ammonium, Sucrose and Cytokinin on Root, Shoot and Microtuber Development in Shoot Cultures of Dioscorea alata L. and D. bulbifera L. Yams," Plant Cell, Tissue and Organ Culture, Vol. 16, No. 1, 1989, pp. 23-37. doi:10.1007/BF00044069

[20] H. Q. Wang and L. T. Xiao, "Effects of Chlorocholine Chloride on Phytohormones and Photosynthetic Characteristics in Potato (Solanum tubersum L.)," Journal of Plant Growth Regulation, Vol. 28, No. 1, 2009, pp. 21-27. doi:10.1007/s00344-008-9069-0

[21] J. Martine and C. Mario, "Effects of Some Growth Gegulator on in Vitro Tuberization in Dioscorea Alata L. 'Brazo Fuerte' and D. abyssinica Hoch," Plant Cell Reports, Vol. 11, No. 1, 1992, pp. 34-38. http://www.springerlink.com/content/b52e1efd7fb94e9e/

[22] C. E. Palmer and O. E. Smith, "Cytokinins and Tuber Initiation in the Potato Solanum tubersum L.," Nature, Vol. 221, 1969, pp. 279-280. doi:10.1038/221279a0

[23] C. S. Mauk and A. R. Langille, "Physiology of Tuberization in Solanum tubersum L.," Plant Physiology, Vol. 62, No. 3, 1978, pp. 438-442. doi:10.1104/pp.62.3.438

[24] H. Obata-Sasamoto and H. Suzuki, "Activities of Enzymes Relating to Starch Synthesis and Endogenous Levels of Growth Regulators during Tuberization of Isolated Potato Stolons Cultured in Vitro," Zeitschrift für Pflanzenphysiologie, Vol. 95, No. 1, 1979, pp. 69-75. http://www.sciencedirect.com/science/article/pii/S004432 8X7980029X

[25] G. Hussey and N. J. Stacey, "Factors Affecting the Formation of in Vitro Tubers of Potato (Solanum tuberosum L.)," Annals of Botany, Vol. 53, No. 4, 1984. pp. 565-578. http://aob.oxfordjournals.org/content/53/4/565.short

[26] S. X. Bai, Z. M. An, X. Z. Feng and J. Wang, "Studies on the Factors Affecting the Induction of in Vitro Potato Microber," China Potato, Vol. 5, No. 15, 2001, pp. 271-273.

[27] H. Y. Yang, D. Wang and X. Pan, "Effect of Hormone and Culture Methods on Potato Microtuber Induction," Journal of Gansu Agricultural University, Vol. 2, 2008, pp. 74-77.

[28] S. Pang, G. N. Fang, J. X. Li and J. X. Zhao, "Effect of Kinds Growth Regulator on Potato Micro-Tubers Induction," Journal of Changjiang Vegetables, Vol. 20, 2009, pp. 25-27.

[29] C. Z. Xu, X. J. Zhang and A. J. Liu, "Effect of Activated Chroal on Explant Growth and Tuberization in Potato," Review of China Agricultural Science and Technology, Vol. 5, 2003, pp. 106-107.

[30] R. X. Liu, "Effect of Activated Charcoal and Inorganic 
Nutrition on the Induction of the Test-Tube Potato," Plant Physiology Journal, Vol. 37, 2001, pp. 295-298.

[31] Y. Luo, H. Tian and T. Zhang, "Effect of Coumarin on
Microtuber Induction in Potato," China Potato, Vol. 1, No. 14, 2000, pp. 4-8. 